\title{
PLANTING TIME FOR MAXIMIZATION OF YIELD OF VINEGAR PLANT CALYX (Hibiscus sabdariffa L.) ${ }^{1}$
}

\author{
Época de plantio para maximização daprodução de cálices de vinagreira (Hibiscus sabdariffa L.)
}

\author{
Nilmar Eduardo Arbex de Castro², José Eduardo Brasil Pereira Pinto ${ }^{3}$, Maria das Graças Cardoso ${ }^{4}$, \\ Augusto Ramalho de Morais ${ }^{5}$, Suzan Kelly V. Bertolucci ${ }^{6}$, Fabiano Guimarães da Silva ${ }^{7}$, Nelson Delú Filho ${ }^{8}$
}

\begin{abstract}
The objective of this work was to evaluate the yield of calyxes of Hibiscus sabdariffa L, a medicinal plant, at four planting times in Lavras - MG. The treatments were four planting times (October $18^{\text {th }}$, November $15^{\text {th }}$, December $18^{\text {th }} 2001$ and January $15^{\text {th }}$ 2002) and a harvest was proceeded when practically there were no developing calyxes, almost at the end of the plant cycle. The numbers of calyxes per plant, the fresh and dry biomasses of calyxes and quality were taken into account. It follows that planting time influenced yield per plant and the fresh and dry biomasses of calyxes, differing from each other by Tukey test at $5 \%$. In October planting, there was a higher yield $(2,522 \mathrm{~kg} / \mathrm{ha})$ with a yield 5.24 as high relative to the planting of the month of January (481 kg/ha). The planting s in the month of November to December showed yields of 1,695 and 1,093 kg/ha of dry calyxes, respectively and in relation to the same months of January, yield was of 3.52 to 2.27 times more. Harvest must be done as soon as the calyxes are ripe in order to preserve quality.
\end{abstract}

Index Terms: Organic farming, calyx, medicinal plant, yield, vinegar plant.

\section{RESUMO}

Objetivou-se avaliar a produtividade de cálices de Hibiscus sabdariffa L., planta medicinal, em quatro épocas de plantio em Lavras - M.G. Os tratamentos foram quatro épocas de plantio (18 de outubro; 15 de novembro; 18 de dezembro de 2001 e 15 de janeiro de 2002) e realizada uma colheita quando praticamente não existiam cálices em desenvolvimento, quase no final do ciclo da planta. Foram considerados os números de cálices por planta, as fitomassas frescas e secas dos cálices e a qualidade. Concluiu-se que a época de plantio influenciou o rendimento por planta e as fitomassas frescas e secas dos cálices, diferindo entre si pelo teste de Tukey a 5\%. No plantio de outubro, houve maior rendimento $(2.522 \mathrm{~kg} / \mathrm{ha})$, com produção de 5,24 vezes a mais em relação ao plantio do mês de janeiro $(481 \mathrm{~kg} / \mathrm{ha})$. Os plantios nos meses de novembro e dezembro tiveram produções de 1.695 e $1.093 \mathrm{~kg} \cdot \mathrm{ha}^{-1}$ de cálices secos, respectivamente, e em relação ao mês de janeiro, a produção foi 3,52 e 2,27 vezes a mais. Deve-se realizar a colheita assim que os cálices estiverem maduros, a fim de preservar a qualidade.

Termos para indexação: Agricultura orgânica, cálice, planta medicinal, produtividade, vinagreira.

(Recebido para publicação em 28 de julho de 2003 e aprovado em 12 de setembro de 2003)

\section{INTRODUCTION}

A native to Tropical Eastern Africa, Hibiscus sabdariffa L. family Malvacea, was introduced in Europe in the late XIX and today is present in the formulation of most aromatic teas consumed in that continent (MARTINS et al., 1994). It is known in England as "roselle", l'oiselle in France, "jamaica" in Spain, "karkade" in Switzerland and Arabia among others (MCCLALEB, 1998).

Introduced in Brazil by the slaves, popularly known by rosele (a), vinagreira, pampola, pampulha, flor da jamaica, azedinha, caruru-azedo, carruru da guiné, quiabo azedo, quiabo-rosco or roxo, joão bento among others (PANIZZA, 1997).

\footnotetext{
1. Parte da dissertação apresentada à Universidade Federal de Lavras/UFLA - Caixa Postal 37 - 37200-000 - Lavras, MG, pelo primeiro autor, para obtenção do grau de mestre em Agronomia, área de concentração Fitotecnia/Plantas Medicinais. 2003. 
Out of the 100 plants of interest by the pharmaceutical industries, the vinegar plant stands out by its therapeutic efficacy as a diuretic, soft laxative, stomatic, calmative, antiscorburtic (VIEIRA, 1992).

It is used also against abscesses, biliary problems, coughs, fevers, hang-overs, heart diseases, hypertension and neurosis (ROVESTI, 1936; LECLERC, 1938; VIEIRA, 1992; PANIZZA, 1997).

Perry (1980) quotes a study performed by Rovesti (1936) with recommendations in arteroscheriose as intestinal antiseptic. It is a food supplement utilized against anemia; its seeds and leaves are ground, powered and served as a nutrient-enriched flour.

Its laxative effect is due to the organic acids present in the calyxes, the most important constituent being hibiscic acid, in addition to lactic, citric, malic and tartaric acids. Also, potassium oxalate, carbohydrates, pigments, glycosides, mucilages, flavonoids (hibiscine and hibiscetine) and anticyanic derivatives (gossipetine and glycoside) which act by decreasing blood viscosity, reducing pressure and stimulating digestion are present. It contain proteins, fibers, calcium, iron, carotenes and vitamin C in leaves (LECLERC, 1938; TESKE and TRENTINI, 1995).

Annual cycle shrub, it reaches up to $1.80 \mathrm{~m}$ high, little branched stem, cup-shaped, glabrous and red tonality (MCCALEB, 1998). Appropriate for the planting in tropical climates with a good rainfall distribution, from 1,500 to $2,000 \mathrm{~mm}$ yearly and altitudes close to $600 \mathrm{~m}$. Frost and shading - susceptible sensitive to photoperiod, which influences directly growth and flowering, decreasing yield as days shorten, which implies in cultivation according to photoperiod (DUKE, 1978).

The flower, single, sessile and axillary possesses its corolla made up of five petals with an average diameter of $5.0 \mathrm{~cm}$ when opened. Five sepals of intense and bright red coloration in a conical shape form the calyx, first floral verticil. At the base of the calyx, the epicalyx or calycle, arranged in circle, giving the impression of a supplementary calyx, is formed by bracts also red. The term calyx in this work involves the properly said calyx and the calycle.

The fruit is an oval dehiscent capsule, $2.0 \mathrm{~cm}$ long, where are inserted seeds and stays involved by the calyx developing after fecundation, which in addition to persistent, it develops and surrounds the fruit in the manner of the juá-de-sapo (Physalis sp) (DUKE, 1978; VIDAL and VIDAL, 1990).

The calyx is the part of greatest interest, for fresh or dehydrated, they are utilized in teas or refreshments of special flavor and taste (TESKE and TRENTINI, 1995), as well as jams (GAMAL et al., 1984), liqueurs, vines, syrups, ice-creams, sauces, pies, vinaigrettes, desserts, dyes and flavorers (SAMBAMURTHY, 1953).

The present work aimed to establish planting time in the obtaining the highest yield of vinagre plant calyxes in Lavras - MG.

\section{MATERIAL AND METHODS}

The experiment was conducted in the Vegetable Sector of the Department of Agriculture of the Federal University of Lavras (UFLA), Minas Gerais State, situated at the geographic coordinates of $21^{\circ} 14^{\prime}$ of South latitude and $45^{\circ} 00$ 'of West longitude with altitude of $920 \mathrm{~m}$. the climate of the local is of the type Cwb by the international climatic classification of Koppen, characterized by rainy summers and dry winters and average annual rainfall of $1,411 \mathrm{~mm}$, the annual average temperature being of $19.3 \mathrm{C}$

Physical-chemical analyses of soil were accomplished in the Soil Analysis laboratory of the Soil Science Department of the UFLA in characterizing the composition of the soil in the experimental area.

The experimental design was the completely randomized with four replicates in order to evaluate the effects of four planting times (November $18^{\text {th }}$; October 15ht; December $18^{\text {th }} 2001$ and January $15^{\text {th }} 2002$ ) of the vinegar plant (Hibiscus sabdariffa) as regards fresh and dried calyx yields per area, only one harvest being performed at the end of fructification.

The conduction of the experiment was achieved according to the precepts of organic farming for medicinal plants (SARTÓRIO et al., 2000).

The spacing utilized at planting was $1.00 \mathrm{~m}$ inter plant by $0.60 \mathrm{~cm}$ inter row with an average density of 16,500 plants/ha. Fertilization utilized was cattle manure $(1.0 \mathrm{~kg} /$ linear meter) in the planting furrow.

In the planting lines were placed three seeds every $0.60 \mathrm{~m}$ at the average depth of 2 to $3 \mathrm{~cm}$. These seeds were obtained from plants grown in the 2000/2001 crop, which were submitted to germination tests. The amount of seeds per hectare was estimated around 1.20 $\mathrm{kg}$. Thinnings were done in the plots when the plants reached the 5 to 6 definitive leaf stage ( 35 to 40 days), leaving only one plant at the indicated spacing.

Harvest was accomplished almost at the end of the plant cycle, when new developing calyxes did not exist any longer. On the occasion of harvest, cycle of the plants (in days), height of the plants (in meter, performed on the stalk since the base to the top); calyx yi- 
eld per plant, fresh and dry biomass of the calyxes (in grams) and the dry calyx yield in $\mathrm{kg} / \mathrm{ha}$.

The data obtained in the evaluations were submitted to the analysis of variance and the effects of planting times were compared by Tukey test and the regression analysis was done (FERREIRA, 200b). Sistema de Análise de Variância (Variance Analysis System) - Sisvar, according to Ferreira (2000a) was utilized.

\section{RESULTS AND DISCUSSIONS}

The soil in the area of the experiment was characterized as a distroferric Red Latosol $=\mathrm{LVdf}$ (EMBRAPA, 1999), analysis of particle size "Very Clayey", pH of 5,5.

Germination test accused $85 \%$ of the seeds viable and good cultural vigor.

In the field, the germination, emergence, development and growth of the plants were similar in all the treatments up to 60 to 70 days, when they were 0.50 to $0.60 \mathrm{~m}$ high. From 70 days up to the end of the cycle, in the plants sown in October and November, increased growth, 1.57 and $1.54 \mathrm{~m}$ high, respectively was found and outgrowing those sown in December $(1.48 \mathrm{~m})$ and January $(1.19 \mathrm{~m})$ and were statistically different from one anther (Figure 1).

According to the $\mathrm{F}$ test at the level of $5 \%$ probability, for plants' height, there were no significant differences between the plantings of the months of October and November, which presented increased heights relative to the months of December and January, pointing out that there is a decrease in the plants' height as planting is delayed from October, becoming marked further in January (Figure 2).

The cycle of plants, viz, the number of days from planting to harvest (DAP) was different at planting times. October enabled a longer cycle (203) days. November provided a 192 day cycle, December, 161 days and January only 149 days. The longest cycles occurred in the plantings of October and November, presupposing that vegetative period is to oc- cur on days where there is greater number of hours' light, supporting increased growth of plants and hence higher yields. Vargas (1960), grown at Tingo Mara (Peru), the species Hibiscus cannabinus $\mathrm{L}$ and $H$. sabdariffa, planted in August and September. Harvest of the former species was done at 135 to 160 (DAP) with growth faster than the latter, even the region being inadequate for growing.

The flowering of plants started at 100 to 105 DAP in the four times. Nevertheless, as the cycles of plants shortened from the first to the last planting time, flowering was also reduced. The maximum flowering (number of flowers per plant and number of flowered plants) occurred around 140 to 145 DAP in October and November. In the plants of December, this period was shorter (125 to 140 DAP), in the plants of January was still shorter (120 to 125 DAP) (Figure 3).

Duke (1978) reports that photoperiod influences directly growth and flowering. Flowering occurred up to the end of the cycle of the plants, always decreasing in the four seasons of planting. Flowers remained open by morning and in the afternoon closed, till next morning when they open again, repeating that every day till fecundation, this being was of 12 to 15 days. After fecundation, petals fell off and the growth of calyxes started at the start 1.0 to $1,5 \mathrm{~cm}$ and when matures of 5.0 to $5,5 \mathrm{~cm}$, after 18 to 23 days. The period of the start of flowering till complete maturation of calyxes ranged from 30 to 38 days in the four times.

The harvested calyx proved fleshy, quite fibrous and calycle marked (Figure $4 \mathrm{~A}$ ). In the inside of the calyx was the fruit (Figure 4 B), an oval capsule $2.0 \mathrm{~cm}$ long, lined with thin trichomes and made up of five loci which opened when dry with six seeds, amounting to 30 seeds, on the average, per fruit. In the seeds, the individual medium dimensions, length and width were $3.0 \times 5.0 \mathrm{~mm}$ and weight $0.0255 \mathrm{~g}$ (weight of 1,000 seeds of $25.5 \mathrm{~g}$ ). The fresh calyx with the capsule weighted, on the average, $6.58 \mathrm{~g}$. 


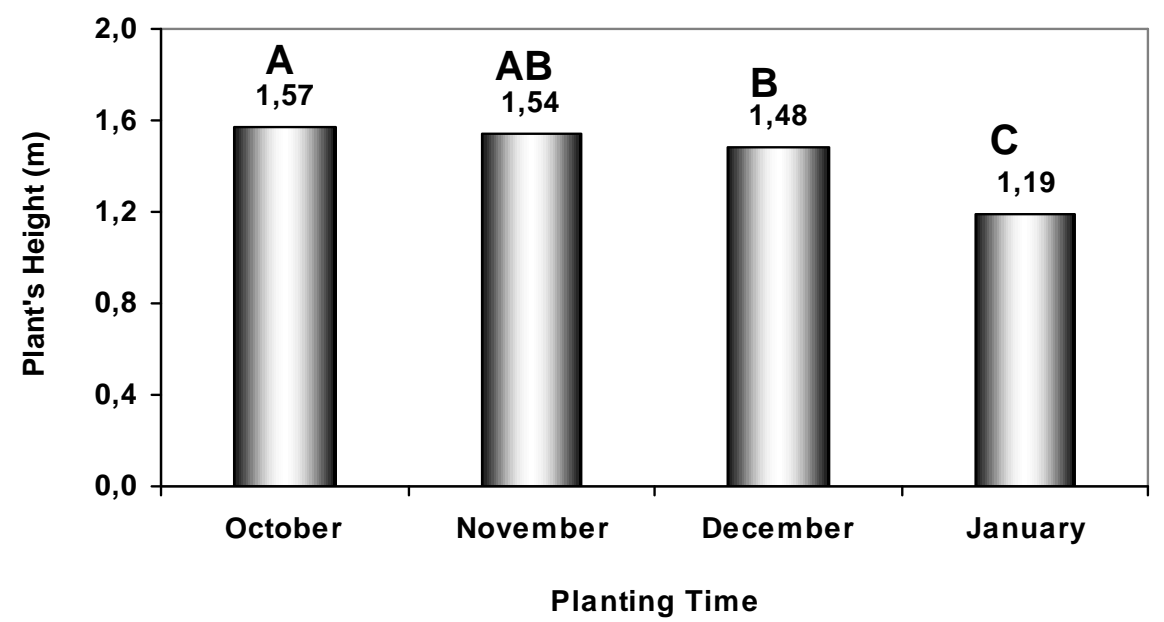

FIGURE 1 - Graphical representation of plant height $(\mathrm{m})$ at planting times of vinegar plant. (UFLA, Lavras - Mg, 2003. Means followed by the same letter do not differ from each other for the characteristics by Tukey's test at 5\%).

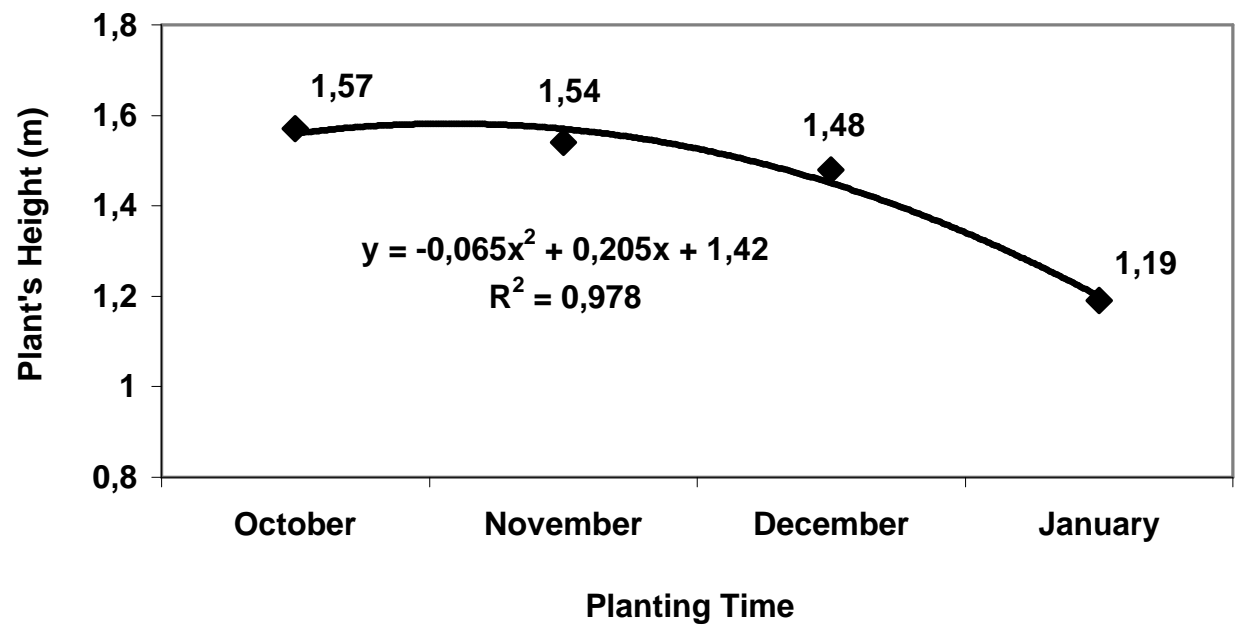

FIGURE 2 - Scatter diagram of plant height (m) at planting times of vinegar plant. UFLA, Lavras-Mg, 2003. (Significant at the level of $5 \%$ by $F$ test). 


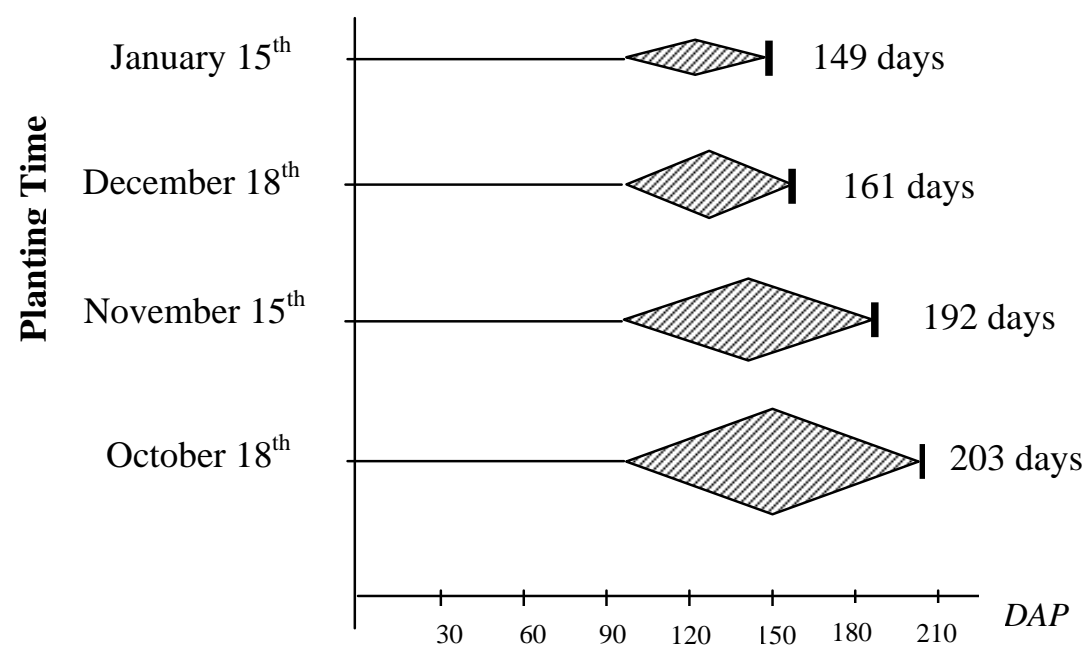

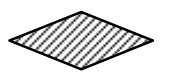
Period of flowering and fructification
I End of the plants cycle

FIGURE 3 - Schematic representation of flowering period, fructification and cycles of the vinegar plants at days after planting (DAP) at planting times. UFLA, Lavras-MG, 2003.
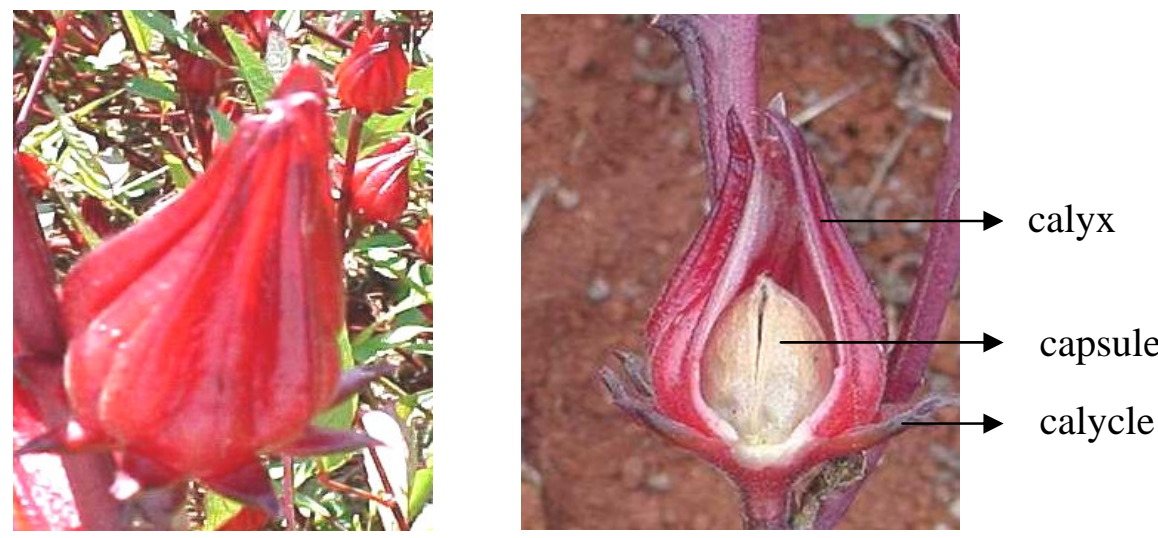

FIGURE 4 - Plates of Hibiscus sabadariffa L. calyxes. A - at 140 days after planting (DAP) and already ripe; B Calyx (external $5.0 \mathrm{~cm}$ long from the top to the base of the calycle or epicalyx) and capsule (internal $2.5 \mathrm{~cm}$ long) UFLA, Lavras-MG, 2003.

The calyxes with the peduncles were harvested by hand by making use of pruning scissors. All the harvests were done at $8 \mathrm{hs}$ and at $12 \mathrm{hs}$ and harvests in the rainy period were avoided.

The number of calyx per plant was significant in planting times. In October, 441 calyxes per plant were found, there being 4.41 as many calyxes per plant as January planting (100 calyxes per plant). November planting yielded 350 calyxes per plant and was as many 3.5 as productive than in January (Figure 5).
According to $\mathrm{F}$ test at the level of $5 \%$ of probability, there was significant difference among planting times for number of calyxes per vinegar plant, showing that there was a reduction in yield of calyxes per plant as planting is delayed from October, which was the most productive month (Figure $6)$.

It was noticed that many of the calyxes past from harvest point and went into senescence, after capsule dehiscence, in addition to favoring the occurrence of 
fungi (Botrytis and Oidio), with losses of quality, they being unsuitable to consumption.

This loss was $20 \%$ of calyxes harvested on October, $40 \%$ November, 30\% December and 10\% January plants. Therefore, harvest should be performed at least 15 days before relative to those non-performed or as soon as calyxes become ripe.
McCaleb (1998) quoted the importance of harvest before capsules drying and opening, for in addition to making handling difficult, drying does not become uniform, undervaluing the quality of calyxes.

The removal of the capsules of the calyxes was done with extractors built aiming at the operation (Figure 7).

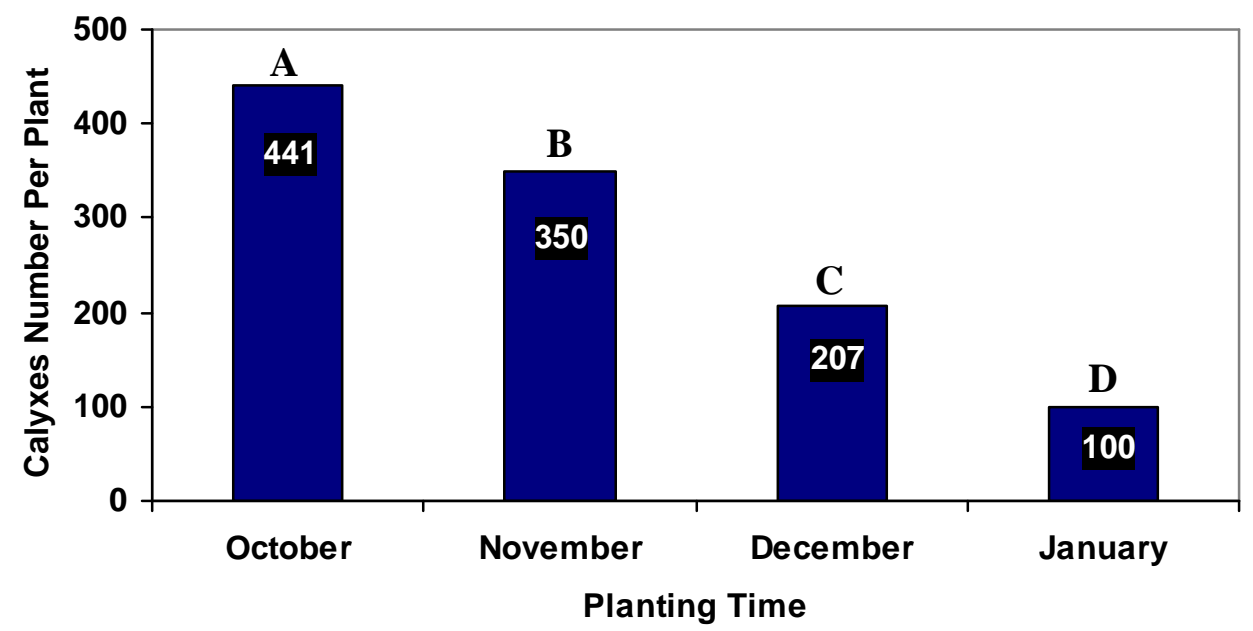

FIGURE 5 - Graphical representations of the numbers of calyxes per vinegar plant at planting times. UFLA, Lavras -MG, 2003. (Means followed by the same letter do not differ from each other for the characteristics by Tukey's test at $5 \%)$.

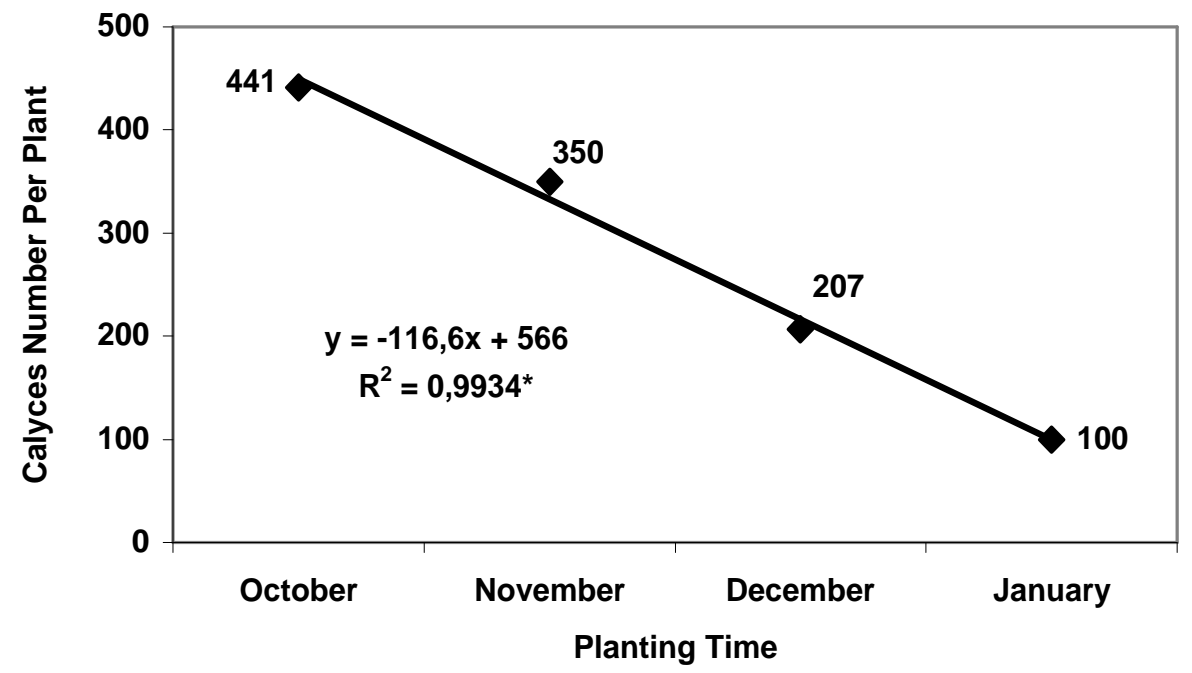

FIGURE 6 - Spread diagram of the number of calyxes per vinegar plant at planting times (*Significant at the level of $5 \%$ by $\mathrm{F}$ test). 
The fresh biomass of the calyx of October plants was of $3.41 \mathrm{~g}$ and did not differ statistically from the fresh biomass of the November calyx $(2.99 \mathrm{~g})$. On the other hand, these ones were superior to those of December $(2.74 \mathrm{~g})$ and January $(2.50 \mathrm{~g})$ plants. In the October plants, the fresh biomass of the calyx was 1.36 as large relative to January. Respectively, November and December presented fresh biomasses of calyxes 1.20 and 1.09 as large as in January (Figure 8).

For October calyx's dry biomass $(0.35 \mathrm{~g})$, the difference was significant and 1.25 as large relative to January $(0.28 \mathrm{~g})$. I the plantings from November to December, the dry biomasses were 0.30 and $0.28 \mathrm{~g}$, respectively and did not differ statistically from January (Figure 9).

By $\mathrm{F}$ test at the level of $5 \%$ of probability, there was a significant difference between planting times for the fresh and dry biomasses of the vinegar plant calyx, pointing that there is a reduction of the calyx biomasses from the month of October, which presented the greatest biomasses (Figures 10 and 11).

The greatest fresh and dry biomass of calyx of the October plants with longer cycles may be ascribed to the longer permanence of the calyxes on the plant, for they grew further, hence they weighted more.

The highest yield of dry biomass of calyxes, in $\mathrm{kg} / \mathrm{ha}$, was on the October plants $(2.522 \mathrm{~kg} / \mathrm{ha})$ and it was 5.2 as large as in January $(480 \mathrm{~kg} / \mathrm{ha})$. In the November planting, it was $1,695 \mathrm{~kg} / \mathrm{ha}$, it being 3.5 as large relative to January. In the December planting, yield was $1,093 \mathrm{~kg} / \mathrm{ha}$, it being 2.3 as large as in January (Figure 12).
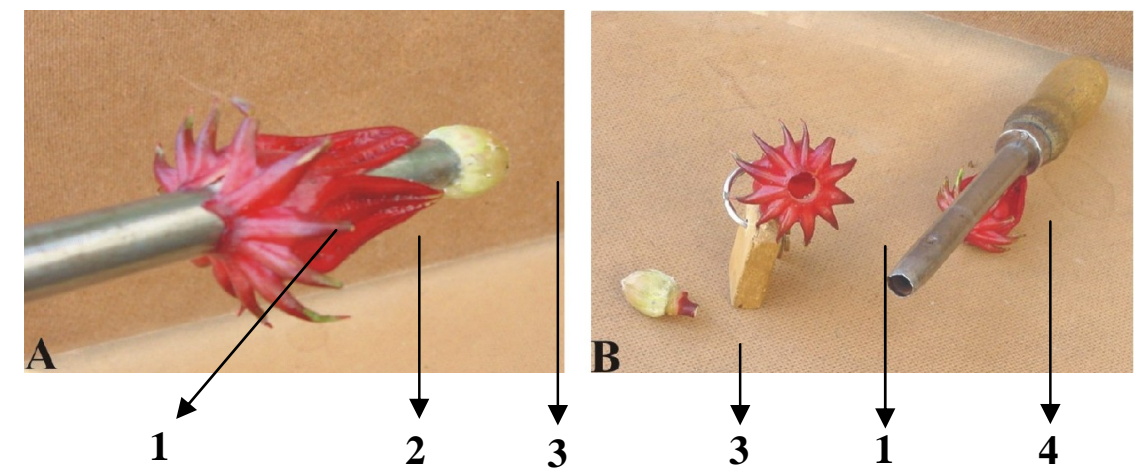

FIGURE 7 - Plates of the extraction of the capsules of vinagreira; A - Extracting the capsule (3) of the calyx and calycle (1); B - Calyx with a calycle (1), capsule already removed (3) and extractor (4), UFLA, Lavras-MG, 2003.
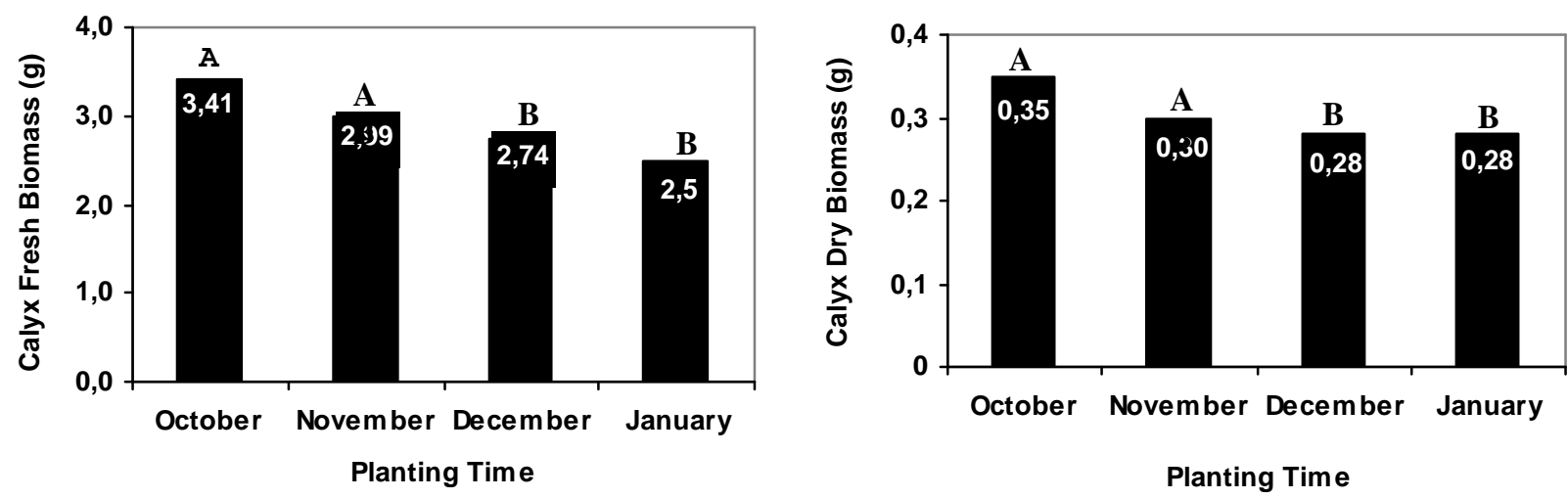

FIGURES 8 and 9 - Graphical representations: 8 - fresh biomass of the vinegar plant calyx; 9 - dry biomass of the vinegar plant calyx at planting times, UFLA, Lavras-MG, 2003.

Ciênc. agrotec., Lavras, v. 28, n. 3, p. 542-551, maio/jun., 2004 
According to $\mathrm{F}$ test at the level of $5 \%$ of probability, there was significant difference between planting times for dry biomass of vinegar plant calyxes in $\mathrm{kg} / \mathrm{ha}$, pointing out that there is a yield reduction as planting was delayed in relation to the month of October, which presented the highest yield (Figure 13).
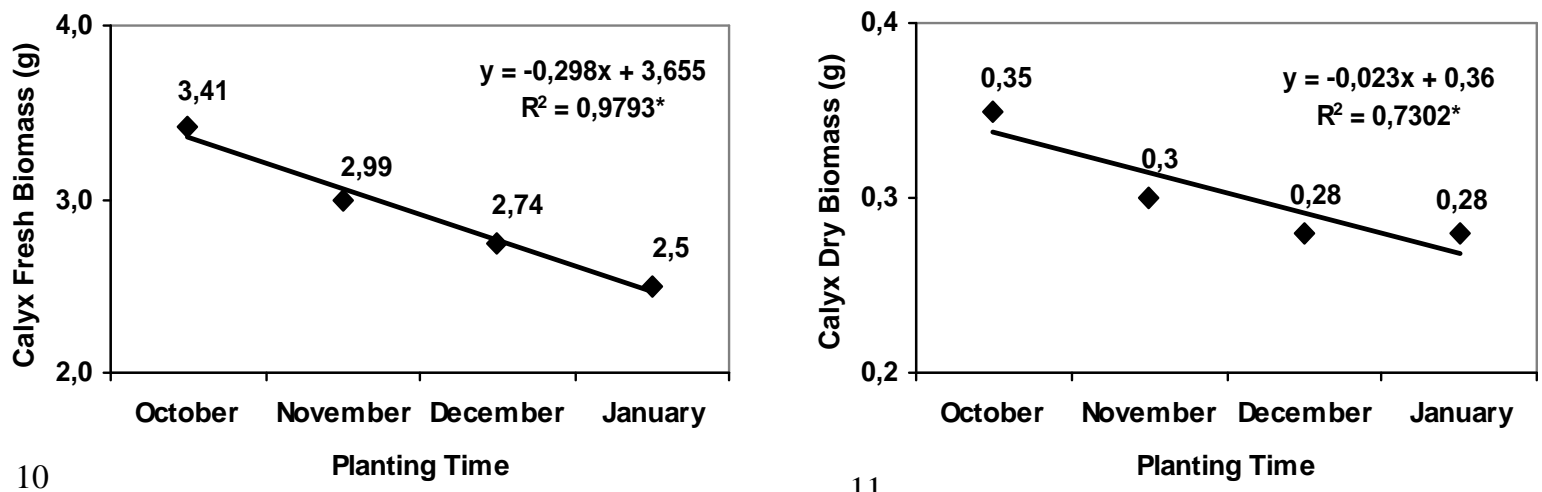

FIGURES 10 and 11 - Spread diagrams of the: 10 - fresh biomass of vinagreira; 11 - dry biomass of the vinegar plant calyx at planting seasons. UFLA, Lavras - MG, 2003. (*Planting time Significant at the level of 5\% by F test).

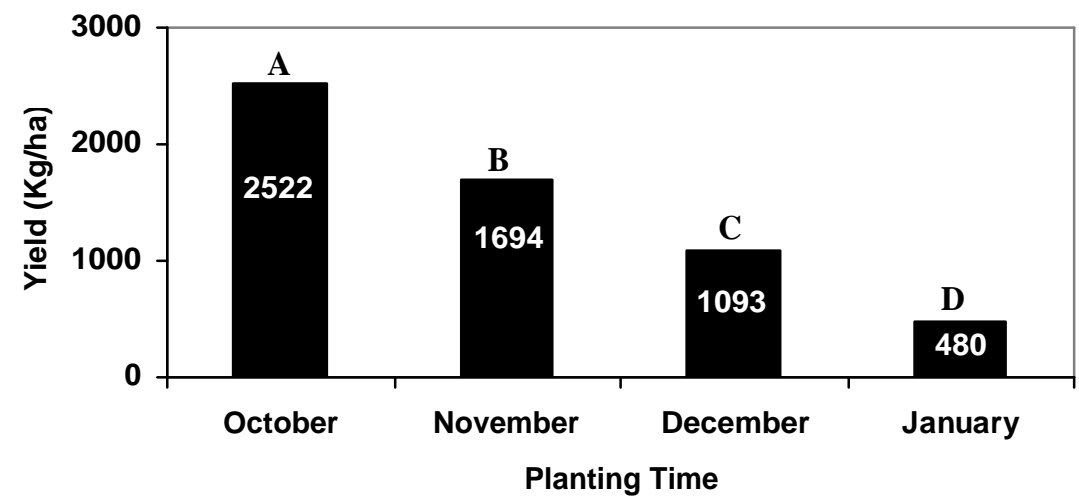

FIGURE 12 - Graphical representation of the dry mass plant yields of vinegar plant calyxes in $\mathrm{Kg} / \mathrm{ha}$ at planting seasons. UFLA, Lavras-MG, 2003. 


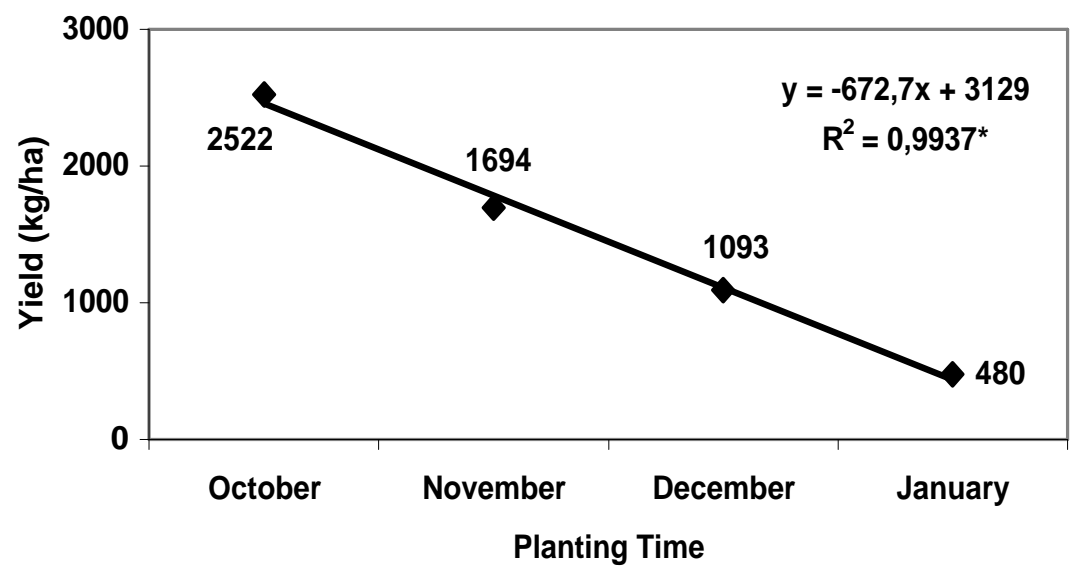

FIGURE 13 - Spread diagram of vinegar plant dry calyx yield in $\mathrm{kg} / \mathrm{ha}$, at planting times. UFLA, Lavras $-\mathrm{Mg}$, 2003. (*Significant at the level of $5 \%$ by $\mathrm{F}$ test).

\section{CONCLUSIONS}

The planting of Hibiscus sabdariffa L. in Lavras, MG, Brazil, may be done in the month of October, under lowland conditions, aiming at increased yield, for in this time, better quality calyxes are obtained. The adequate harvest time avoids quality loss by calyxes' senescence or by pathogen attack.

Further studies are necessary as to the sort of harvest (in scale and single) in order to preserve the quality of the calyxes as well as to evaluate the yield and quality of the organic compounds present in the vinegar plant calyxes.

\section{ACKNOWLEDGEMENTS}

To the Coordenação de Aperfeicoamento de Pessoal de Nível Superior - CAPES, by the grant of scholarship to the first author.

\section{BIBLIOGRAPHICAL REFERENCES}

DUKE, J. A. The quest for tolerant germplasm. In: Crop tolerance to suboptimal land conditions. Madison: American Society of Agronomy, 1978. p. 161. (ASA Special System, 82).

EMPRESA BRASILEIRA DE PESQUISA AGROPECUÁRIA. Centro Nacional de Pesquisa de Solos. Sistema brasileiro de classificação de solos. Brasília, 1999. $412 \mathrm{p}$.
FERREIRA, D. E. Análise estatística por meio do sisvar para windows: versão 4.0. In: REUNIÃO ANUAL DA REGIÃO BRASILEIRA DA SOCIEDADE INTERNACIONAL DE BIOMETRIA, 45., 2000, São Carlos. Anais... São Carlos: UFSCar, 2000a. p. 255-258.

FERREIRA, P. V. Estatística experimental aplicada à agronomia. 3. ed. Maceió: EDUFAL, 2000b. 422 p.

GAMAL, S. A. El; OMAR, F. A.; MAHMOUD, M. M. Effect of nitrogen fertilization on the grouwth and yield of the Hibiscus sabdariffa L. Acta Horticulture, Cairo, n. 144 , p. 135-144, 1984.

LECLERC, H. (Sida sabdariffa L.). Presse Médicale, Paris, v. 46, p. 1060, 1938.

MARTINS, E. R.; CASTRO, D. M.; CASTELLANI, D. C.; DIAS, J. E. Plantas medicinais. Viçosa: UFV, 1994. 220 p.

McCALEB, R. S. Hibiscus production manual. [S.1.: s.n.], 1998.

PANIZZA, S. Plantas que curam: cheiro de mato. 18. ed. São Paulo: IBRASA, 1997. p. 69-70.

PERRY, L. M. Medicinal plants of east and southeast Asia. Cambridge: MIT, 1980.

ROVESTI, P. Therapeutic and dietetic properties of "karkade" (Hibiscus sabdariffa L. ), a new colonial pink tea. Farmacista Ital, Cambridge, v. 3, n. 1, p. 13-16, 1936. 
SAMBAMURTHY, K. A note on rosele: a useful economic plant. Madras Agricultural Journal, Madras, v. 40, n. 11, p. 503-505, Nov. 1953.

SARTÓRIO, M. L.; TRINDADE, C.; RESENDE, P.; MACHADO, J. R. Cultivo orgânico de plantas medicinais. Viçosa: Aprenda Fácil, 2000. 260 p.

TESKE, M.; TRENTINI, A. M. M. Compêndio de fitoterapia. 3. ed. Curitiba: Herbarium Laboratório Botânico, 1995. $317 \mathrm{p}$.
VARGAS, M. J. Abaca y kenaf: dos cultivos para nuestro oriente. Bolletin Estacion Experimental Agricola de Tingo Maria, Huanucu, p. 6, 1960.

VIDAL, W. N.; VIDAL, M. R. R. Organografia botânica. 3. ed. Viçosa: UFV, 1990.

VIEIRA, L. S. Fitoterapia da Amazônia: manual das plantas medicinais, a farmácia de Deus. 2. ed. São Paulo: Agronômica Ceres, 1992. 347 p. 